\title{
KEANEKARAGAMAN BINTANG MENGULAR (OPHIUROIDEA) DI PERAIRAN DESA MOKUPA, KECAMATAN TOMBARIRI, KABUPATEN MINAHASA
}

\author{
Selly Lesawengan ${ }^{1)}$, Marnix L.D. Langoy ${ }^{1)}$, Lalu Wahyudi ${ }^{1)}$ \\ ${ }^{1)}$ Program Studi Biologi, FMIPA Universitas Sam Ratulangi Manado
}

\begin{abstract}
Ophiuroids are well known called brittle star which is one member of the Phylum Echinodermata. Brittle stars have an important ecological role in the food chain that can support marine ecosystem. Brittle star are currently have no economic importance. However, the genus ophioderma can be used as aquarium decoration because it has an attractive color. This research aims to determine the level of diversity of brittle stars in Mokupa waters, Tombariri District, Minahasa Regency using the Shannon-Wiener diversity index. This research was conducted in June 2018 applying quadrant transect method. Species of brittle stars found there are 7 types of Macrophiothrix longipeda, Ophiomastix janualis, Ophiocoma brevipes, Ophiocoma schoenleinii, Ophiomastix annulosa, Ophiocoma scolopendrina and Ophiolepis cincta. Ophiomastix janualis is dominant species but not for Ophiocoma brevipes. Ophiuroids diversity in the Mokupa waters was classified into moderate class with a diversity index of 1,475
\end{abstract}

Keywords: Brittle Star, Diversity, Minahasa Regency.

\begin{abstract}
ABSTRAK
Bintang mengular (Ophiuroidea) merupakan salah satu kelas yang tergolong dalam filum Echinodermata. Fungsi ekologis bintang mengular yaitu memegang peran penting dalam rantai makanan yang menopang suatu bentuk ekosistem di laut. Dari sudut ekonomi belum diketahui nilai ekonomis dari bintang mengular namun khususnya dari genus Ophioderma bisa dijadikan sebagai hiasan aquarium karena memiliki warna yang menarik. Penelitian ini bertujuan untuk menentukan tingkat keanekaragaman bintang mengular di perairan Desa Mokupa, Kecamatan Tombariri, Kabupaten Minahasa berdasarkan nilai indeks ShannonWiener. Penelitian ini dilaksanakan pada bulan Juni 2018 dengan menggunakan metode transek kuadrat. Berdasarkan hasil penelitian terdapat 7 jenis yang ditemukan yaitu, Macrophiothrix longipeda, Ophiomastix janualis, Ophiocoma brevipes, Ophiocoma schoenleinii, Ophiomastix annulosa, Ophiocoma scolopendrina dan Ophiolepis cincta. Bintang mengular yang paling banyak ditemukan adalah Ophiomastix janualis dan yang paling sedikit adalah Ophiocoma brevipes. Indeks keanekaragaman dari bintang mengular yang diamati termasuk dalam kategori sedang yaitu 1,475.
\end{abstract}

Kata kunci: Bintang mengular, Keanekaragaman, Kabupaten Minahasa. 


\section{PENDAHULUAN}

Indonesia merupakan negara kepulauan yang memiliki sumber kekayaan laut dan potensial untuk dimanfaatkan. Luas perairan Indonesia mencapai 5,8 juta $\mathrm{km}^{2}$ dan memiliki garis pantai sepanjang $81.000 \mathrm{~km}$. Karakteristik perairan Indonesia yang sangat spesifik menimbulkan keragaman berbagai jenis biota laut yang tinggi, antara lain bintang mengular (Dahuri, 2001). Bintang mengular adalah salah satu kelas dalam filum Echinodermata yang bentuknya menyerupai bintang laut, namun memiliki lengan yang lebih panjang dan rapuh atau mudah putus (Romimohtarto dan Juwana, 2001). Secara ekologis, bintang mengular memiliki peranan yang penting dalam rantai makanan yang menopang suatu bentuk ekosistem di laut dan biasanya dapat ditemukan di karang bersama dengan biota laut yang kecil seperti moluska, kepiting kecil dan udang (Morris dan Fautin, 2001). Bintang mengular memiliki kemampuan regenarasi yang besar, lengan dapat beregenarasi pada setiap titik tetapi apabila semua bagian tubuh terpisah dari semua lengan maka hewan ini akan mati. Bintang mengular ini dengan mudah melepaskan lengannya apabila diserang pemangsa (Rompis, 2012). Biodiversitas bintang mengular dapat dijadikan sebagai bioindikator tercemarnya perairan dan berperan penting bagi ekosistem laut dan bermanfaat sebagai salah satu komponen dalam rantai makanan, pemakan sampah organik dan hewan kecil lainnya.

Perairan Sulawesi Utara memiliki beragaman habitat untuk penyebaran bintang mengular. Salah satu lokasi yang memiliki tipe habitat untuk bintang mengular ialah perairan Desa Mokupa.
Perairan Desa Mokupa sebagai salah satu objek wisata yang berada di Sulawesi Utara menyebabkan habitat bintang mengular semakin berkurang, sehingga tidak ada tempat bagi bintang mengular untuk berkembang biak dengan baik. Walaupun demikian, perairan Desa Mokupa masih memiliki beragam habitat yang dapat mendukung kehidupan bintang mengular.

Jenis bintang mengular di perairan Desa Mokupa Kecamatan Tombariri belum diketahui dengan pasti. Hal ini disebabkan masih kurangnya perhatian yang khusus ditujukan untuk meneliti bintang mengular di daerah ini. Oleh karena itu perlu dilakukan penelitian tentang keanekaragaman bintang mengular di perairan Desa Mokupa Kecamatan Tombariri Kabupaten Minahasa sehingga dapat melengkapi data mengenai kekayaan jenis bintang mengular di Sulawesi Utara. Penelitian ini bertujuan untuk menentukan tingkat keanekaragaman jenis-jenis bintang mengular (Ophiuroidea) yang ada di perairan Desa Mokupa Kecamatan Tombariri Kabupaten Minahasa.

\section{METODOLOGI PENELITIAN}

Penelitian ini dilaksanakan pada bulan Juni 2018 selama 3 hari di perairan Desa Mokupa Kecamatan Tombariri Kabupaten Minahasa. Pengambilan data dan sampel pada lokasi penelitian dilakukan pada saat air surut terendah hingga air mulai pasang. Pengambilan data menggunakan metode transek kuadrat. Transek dibuat dengan cara menarik tali rafia sebagai garis tegak lurus dari bibir pantai menuju laut dengan panjang $100 \mathrm{~m}$. Setiap 10 meter dibuat plot kecil berukuran $1 \mathrm{~m} \times 1 \mathrm{~m}$. Transek 
dibuat sebanyak tiga buah dengan jarak masing-masing transek adalah $50 \mathrm{~m}$. Pada plot kecil yang terdapat pada setiap transek dilakukan pengamatan dengan mencatat bintang mengular yang

\section{HASIL DAN PEMBAHASAN \\ Deskripsi Lokasi Penelitian}

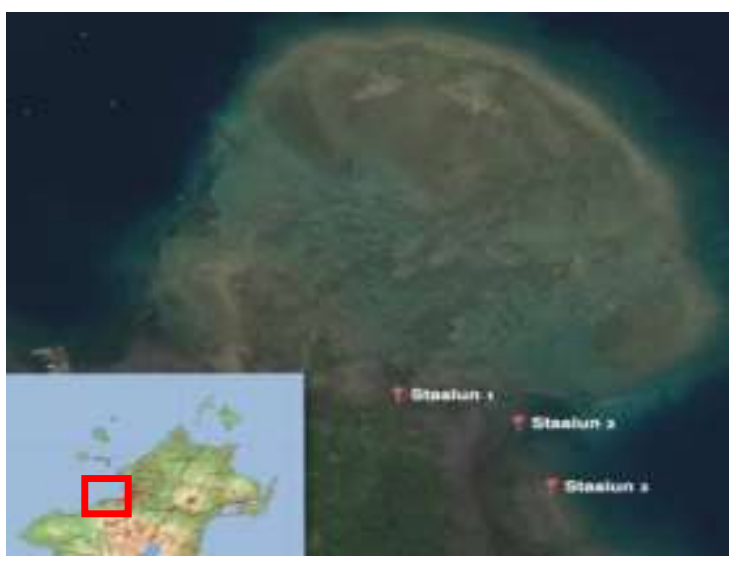

Gambar 1. Lokasi penelitian

Lokasi penelitian terletak di Desa Mokupa Kecamatan Tombariri Kabupaten Minahasa. Letak geografi di lokasi penelitian yaitu di transek $1\left(01^{\circ} 24^{\prime} 59^{\prime \prime} \mathrm{L}\right.$ ditemukan serta nama jenisnya. Proses identifikasi dilakukan dengan cara mengamati karakteristik morfologi seperti warna tubuh, duri tubuh, bentuk pisin (cakram pusat) dan bentuk lengan.

dan 124'42'24'BT), transek 2 $\left(01^{\circ} 25^{\prime} 01^{\prime \prime} \mathrm{LU}\right.$ dan $\left.124^{\circ} 42^{\prime} 24^{\prime \prime} \mathrm{BT}\right)$ dan transek $3 \quad\left(01^{\circ} 25^{\prime} 03^{\prime \prime} \mathrm{LU}\right.$ dan $124^{\circ} 42^{\prime} 23^{\prime \prime}$ 'BT). Habitat lokasi penelitian merupakan variasi campuran pasir, padang lamun dan terumbu karang dan juga terdapat mangrove. Lokasi transek I merupakan daerah pinggiran mangrove bersubstrat pasir, Transek II merupakan daerah bersubstrat pasir, terumbu karang dan lamun yang banyak ditumbuhi lamun jenis Cymodocea serrulata dan transek III merupakan daerah rataan karang yang termasuk karang hidup dan karang mati dan juga terdapat lamun. Kondisi lingkungan di perairan Desa Mokupa saat surut terendah di siang hari memiliki $\mathrm{pH} 7$ - 8. Suhu pada lokasi ini $29^{\circ} \mathrm{C}-33^{\circ} \mathrm{C}$, salinitas $30 \%$ - 33\%o.

Tabel 1. Kepadatan Bintang Mengular pada masing-masing transek (individu/ $\mathrm{m}^{2}$ )

\begin{tabular}{|c|c|c|c|c|c|}
\hline \multirow{2}{*}{ No. } & \multirow{2}{*}{ Spesies } & \multicolumn{3}{|c|}{ Transek } & \multirow{2}{*}{$\bar{X}$} \\
\hline & & I & II & III & \\
\hline 1 & Macrophiothrix longipeda & 0.06 & 0.16 & 0.03 & 0.08 \\
\hline 2 & Ophiomastix janualis & 0 & 2.16 & 1.73 & 1.29 \\
\hline 3 & Ophiocoma brevipes & 0 & 0.03 & 0.06 & 0.03 \\
\hline 4 & Ophiocoma schoenleinii & 0.16 & 0.02 & 0.16 & 0.53 \\
\hline 5 & Ophiomastix annulosa & 0.03 & 0.53 & 1.13 & 0.56 \\
\hline 6 & Ophiocoma scolopendrina & 0.7 & 1.1 & 0.3 & 0.7 \\
\hline 7 & Ophiolepis cincta & 0.03 & 0.2 & 0.13 & 0.12 \\
\hline
\end{tabular}

Dari ketiga transek yang memiliki kepadatan tertinggi yaitu Ophiomastix janualis dengan kepadatan rata-rata 1,29 individu $/ \mathrm{m}^{2}$. Hal ini dikarenakan spesies ini menyukai patahan karang yang ditumbuhi alga dan lamun yang dapat menyediakan makanan dan juga sebagai tempat berlindung. Jenis ini juga memiliki banyak susunan duri pada sekujur tubuhnya yang dapat menghalangi pemangsaan dan rangka tubuh yang fleksibel yang memungkinkan hewan ini menyembunyikan cakram pusat dibawah celah batu yang ukurannya lebih kecil dari ukuran tubuhnya (Brotowidjoyo, 1993). Hal ini dipandang sebagai kemampuan spesies tersebut dalam beradaptasi dengan lingkungan perairan serta substrat yang ada. Ophiocoma brevipes memiliki kepadatan rata-rata terendah yaitu 0,03 individu $/ \mathrm{m}^{2}$. Hal ini dikarenakan jenis ini menyukai daerah yang terlindung dari 
sinar matahari, predator dan arus, misalnya bersembunyi dibalik batu atau patahan karang sehingga jarang terlihat dalam penelitian.

Tabel 2. Kelimpahan Relatif Bintang Mengular pada masing-masing transek

\begin{tabular}{ccccccc}
\hline \multirow{2}{*}{ No. } & \multirow{2}{*}{ Nama } & I & Transek & II & Total & \multirow{2}{*}{ KR } \\
\hline 1 & Macrophiothrix longipeda & 2 & 5 & 1 & 8 & 2.88 \\
2 & Ophiomastix janualis & 0 & 65 & 52 & 17 & 42.09 \\
3 & Ophiocoma brevipes & 0 & 1 & 2 & 3 & 1.08 \\
4 & Ophiocoma schoenleinii & 5 & 6 & 5 & 16 & 5.76 \\
5 & Ophiomastix annulosa & 10 & 16 & 34 & 60 & 21.58 \\
6 & Ophiocoma scolopendrina & 21 & 33 & 9 & 63 & 22.66 \\
7 & Ophiolepis cincta & 1 & 6 & 4 & 11 & 3.96 \\
\hline & TOTAL & 39 & 132 & 107 & 278 & \\
\hline
\end{tabular}

Dari ketiga transek yang memiliki kelimpahan relatif tertinggi yaitu Ophiomastix janualis dengan nilai kelimpahan relatif $42,09 \%$ dengan total individu sebanyak 117 individu. Ophiocoma brevipes memiliki kelimpahan relatif terendah yaitu $0,3 \%$ dengan jumlah total individu yaitu 3 individu. Kelimpahan relatif sangat dipengaruhi oleh jumlah individu dari masing-masing spesies bintang mengular yang dijumpai selama pengamatan. Karakteristik tiap transek yaitu dimana pada Transek II memiliki jumlah individu yang tertinggi, hal ini disebabkan oleh lokasi tersebut bersubstrat pasir, terumbu karang dan bercampur lamun merupakan daerah yang mendukung kelangsungan hidup organisme bintang mengular, dalam hal ini dapat memberikan pilihan dari variasi makan dan tempat hidup yang memungkinkan spesies tersebut dapat bertahan dan hadir di tempat itu (Desmukh, 1992). Pada transek III memiliki jumlah individu tertinggi kedua dengan lokasi bersubtrat pasir, lamun dan karang hidup dan karang mati. Pada Transek I memiliki jumlah individu yang terendah dimana lokasi tersebut bersubstrat pasir. Peningkatan jumlah individu dari spesies terjadi pada suatu daerah dengan subtrat yang beragam.

Tabel 3. Indeks keanekaragaman bintang mengular di Desa Mokupa Kecamatan Tombariri Kabupaten Minahasa.

\begin{tabular}{lcccccc}
\hline \multicolumn{1}{c}{ Jenis Ophiuroidea } & Jumlah & Ni/N & pi & Ln pi & pi Ln pi & H' \\
\hline Macrophiothrix longipeda & 8 & 0.029 & 0.029 & -3.548 & -0.102 & \\
Ophiomastix janualis & 117 & 0.421 & 0.421 & -0.865 & -0.364 & \\
Ophiocoma brevipes & 3 & 0.011 & 0.011 & -4.529 & -0.049 & \\
Ophiocoma schoenleinii & 16 & 0.058 & 0.058 & -2.855 & -0.164 & 1.475 \\
Ophiomastix annulosa & 60 & 0.216 & 0.216 & -1.533 & -0.331 & \\
Ophiocoma scolopendrina & 63 & 0.227 & 0.227 & -1.484 & -0.336 & \\
Ophiolepis cincta & 11 & 0.040 & 0.040 & -3.229 & -0.128 & \\
\hline Total & 278 & 1 & 1 & -18.05 & -1.475 & \\
\hline
\end{tabular}

Berdasarkan hasil pengamatan terdapat 5 jenis bintang mengular yang ditemukan di semua transek yaitu Macrophiothrix longipeda, Ophiomastix 
annulosa, Ophiocoma schoenleinii, Ophiocoma scolopendrina, Ophiolepis cincta. Sementara jenis bintang mengular yang hanya ditemukan di beberapa transek yaitu Ophiomastix janualis dan

sedangkan jenis bintang mengular yang hanya ditemukan di beberapa transek mempunyai arti bahwa transek tersebut tidak sesuai bagi kebutuhan tempat untuk kehidupan bintang mengular. Jika dibandingkan dengan penelitian di tempat lain memiliki indeks keanekaragaman yang tergolong tinggi. Yusron (2010) meneliti tentang keanekaragaman jenis ophiuroidea (bintang mengular) di perairan Wori, Minahasa Utara, Sulawesi Utara. Hasil penelitian menemukan 10 jenis ophiuroidea dengan jumlah populasi sebanyak 324 individu. Indeks keanekaragaman jenis sebesar (H') 4,276, hal ini dikarenakan jumlah jenis yang ditemukan banyak dan kondisi habitat yang masih baik.

\section{KESIMPULAN}

Indeks keanekaragaman dari bintang mengular yang ada di perairan desa Mokupa termasuk dalam kategori sedang dengan nilai $\mathrm{H}^{\prime}=1,475$. Jenis bintang mengular yang ditemukan adalah Macrophiothrix longipeda, Ophiomastix janualis, Ophiocoma brevipes, Ophiocoma schoenleinii, Ophiomastix annulosa, Ophiocoma scolopendrina, Ophiolepis cincta.

\section{SARAN}

Perlu dilakukan penelitian lanjutan
tentang keanekaragaman kelas Ophiuroidea untuk menambah informasi tentang keberadaan organisme dari kelas Ophiuroidea yang ada di Sulawesi Utara.
Ophiocoma brevipes. Jenis bintang mengular yang ditemukan di tiap transek mempunyai arti bahwa habitat tersebut sesuai dengan kehidupan jenis bintang mengular yang ada,

\section{DAFTAR PUSTAKA}

Brotowidjyo, M, D. 1993. Zoologi Dasar Cetakan II. Jakarta : Erlangga.

Dahuri, R. 2001. Pengelolaan Sumber Daya Wilayah Pesisir dan Lautan Secara Terpadu. Jakarta : Pradnya Paramita.

Desmukh, I. 1992. Ekologi dan Biologi Tropika. Jakarta : Yayasan Obor Indonesia.

Morris, M. D, Fautin, 2001. Ophiuroidea. Animal Diversity Web.

Romimohtarto, K. S, Juwana. 2001. Biologi Laut. Ilmu Pengetahuan Tentang Biota Laut. Penerbit Djambatan. Jakarta.

Rompis, R. 2012. Diversitas Echinodermata di Pantai Meras, Kecamatan Bunaken. Sulawesi Utara. Jurnal Biologos III (1): 2630.

Yusron, E. 2010. Keanekaragaman jenis ophiuroidea (bintang mengular) di perairan Wori, Minahasa Utara, Sulawesi Utara. Makara Sains 14(1): 75-78 